EL MUHASABA: Jurnal Akuntansi (e-Journal)

Volume 13 , No. 1, Tahun 2022

P ISSN: 2086-1249 ; E ISSN: 2442-8922

\title{
KAJIAN LITERATUR: PENGARUH TATA KELOLA PERUSAHAAN PADA PERFORMA KEUANGAN
}

\author{
Felicia Siswanto', I Wayan Alvin Kertanegara², Kevin³ ${ }^{3}$ Rahayu Ningsih", Carmel \\ Meiden $^{5}$ \\ Institut Bisnis dan Informatika Kwik Kian Gie',2,3,4,5, Jl. Yos Sudarso Kav 85 No.87 Sunter, \\ 14350, Indonesia \\ e-mail: feliciasiswanto3008@gmail.com ${ }^{1}$
}

\section{Abstract}

The purpose of the study was to identify the elements that affect corporate governance. Corporate governance is a picture of the relationship between parties that influences the direction of the company and financial performance. Basically, to find out how much influence corporate governance has on a company's financial performance requires the application of agency theory. This research uses a method of literature studies that studies and examines documents related to corporate governance especially about the influence of corporate governance on financial performance. The data used in this study is secondary data. The implementation of corporate governance should have a positive impact on the performance of the company, but in reality there are still many companies that have not implemented good corporate governance, because most companies only carry out government rules without deepening the role and function of corporate governance itself.

Keywords: good corporate governance; financial performance; study literature

\section{Abstrak}

Tujuan dari penelitian ini adalah untuk mengidentifikasi unsur-unsur yang mempengaruhi Good Corporate Governance (GCG). GCG adalah gambaran hubungan antara pihak yang mempengaruhi arah perusahaan dan performa keuangan. Pada dasarnya, untuk mengetahui seberapa besar pengaruh GCG pada performa keuangan perusahaan diperlukan penerapan teori agensi. Penelitian ini mengenakan metode studi literatur yang mempelajari dan meneliti dokumen yang berhubungan dengan GCG terutama tentang pengaruh GCG pada performa keuangan. Data yang digunakan dalam penelitian ini adalah data dari pihak kedua. Penerapan GCG seharusnya bisa memberikan dampak positif pada performa perusahaan, tetapi pada kenyataannyabanyak perusahaan yang masih belum menerapkan tata kelola perusahaan dengan baik, karena sebagian besar perusahaan hanya menjalankan aturan pemerintah tanpa memperdalam peran dan fungsi dari GCG itu sendiri.

Kata kunci: tata kelola perusahaan yang baik; performa keuangan; studi literatur 
Felicia Siswanto', I Wayan Alvin Kertanegara', Kevin'3, Rahayu Ningsih4, Carmel

Meiden $^{5}$ : Kajian Literatur: Pengaruh Tata Kelola PerusahaanPadaPerforma Keuangan

\section{PENDAHULUAN}

Peristiwa krisis ekonomi global Indonesia di tahun 1997 memberi dampak negatif terhadap performa keuangan perusahaan. Merebaknya krisis ini dipandang sebagai implementasi GCG yang buruk dan kurangnya transparansi perusahaan, yang pada akhirnya pengawasan publik menjadi lemah dan menyimpang dari GCG yang baik dari pemegang saham (Syamsuri Rahim: 2003 dalam Wahyuni et al., 2020). Dengan terjadinya krisis ini, pemerintah Indonesia membentuk sebuah Komite Nasional Kebijakan GCG pada tahun 1999 sesuai dengan Keputusan Menko Ekuin Nomor KEP/31/M.EKUIN/08/1999 guna menyelesaikan masalah pengelolaan perusahaan di Indonesia. Setelah kebangkrutan perusahaan besar, krisis ekonomi di berbagai negara, dan skandal akuntansi pentingnya penerapan GCG di perusahaan semakin ditekankan. Salah satu contoh dari skandal akuntansi adalah kasus Enron pada 15 Juni 2002 yang menyeret Arthur Andersen, satu dari lima Kantor Akuntan Publik (KAP) terbesar ke pengadilan. Tanggal 31 Mei 2005, KAP memberhentikan kegiatan auditnya dan mengurangi operasi bisnisnya meskipun gugatan tersebut telah diselesaikan (Sulaiman et al. 2021). Konsep GCG diterapkan demi tercapainya pengelolaan perusahaan yang baik, sehingga perusahaan akan lebih terbuka kepada semua pengguna laporan keuangan. Dengan diterapkannya GCG diharapkan akan adanyapeningkatan pertumbuhan ekonomiseiring dengan keterbukaan perusahaan yang nantinya menguntungkan berbagai belah pihak (Nasution dan Setiawan, 2007).

Konsep GCG berasal dari teori agensi yang diutarakan oleh Jensen dan Meckling, (1976), menjelaskan hubungan dua pihak yang terdapat dalam perusahaan, yaitu antara pihak pemilik (principal) dan manajemen (agen). Pada situasi ini, pihak manajemen (agen) mengetahui berbagai hal tentang situasi yang sebenarnya mengenai suatu perusahaan. GCG merupakan faktor dalam meningkatkan efisiensi ekonomi dan performa (Sudrajat dan Sukmajati, 2018). Dari segi performa keuangan, laporan keuangan merupakan tolak ukur yang mengukur seberapa baik performa suatu perusahaan dapat dipertimbangkan. Definisi performa keuangan perusahaan merupakan suatu analisis untuk mengetahui seberapa akurat dan benar aturan pelaksanaan keuangan perusahaan tersebut (Delta dan Sutarjo, 2020). Dari laporan keuangan, investor dapat meninjau bagaimana cara perusahaan untuk dapat menggunakanasetnya secara optimal dengan efektif dan efisien yang bertujuan untuk memaksimalkan laba yang menjadi tujuan penerapan GCG (Sari et al., 2019).

Persaingan dalam dunia bisnis yang sangat kompetitifmembuat perusahaan harus berlomba-lomba memberikan performa yang baik dengan cara mengelola perusahaannya dengan baik. Selain itu keterbukaan perusahaan kepada publik juga diutamakan hal ini bertujuan agar semua informasi keuangan perusahaan dapat diungkapkan dengan akurat dan tepat waktu. Penerapan GCG sebagai pedoman dalam mengelola perusahaan dapat meningkatkan kepercayaan investor terhadap perusahaan. 
Felicia Siswanto', I Wayan Alvin Kertanegara², Kevin³, Rahayu Ningsih", Carmel

Meiden $^{5}$ : Kajian Literatur: Pengaruh Tata Kelola PerusahaanPadaPerforma Keuangan

Penerapan GCG yang baik akan membuat investor mempercayakan modalnya untuk ditanamkan kepada perusahaan tersebut, karena investor melihat performa yang baik dalam perusahaan.

Good Corporate Governance(GCG) menjadi salah satu dari sekian banyak permasalahan yang berdampak pada banyak perusahaan dari berbagai negara. Salah satu isu yang berkaitan dengan GCG yaitu pada PT Garuda Indonesia (Persero). Wakil Menteri BUMN Kartika Wirjoatmodjo mengatakan performa PT Garuda Indonesia memburuk cukup lama akibat GCG yang begitu buruk, selain itu PT Garuda Indonesia (Persero) memiliki hubungan Kerjasama yang tidak menguntungkan perusahaan, ditambah lagi dengan berbagai kasus, seperti kasus penerimaan suap, pencucian uangdan mark up nilai pesawat selama tahun 2011 s/d 2012 memiliki kerja sama yang memberatkan pihak perusahaan, menaikan nilai pesawat serta kasus pencucian uang dan penerimaan suap yang berlangsung pada tahun 2011 hingga 2012. Sekarang ini Garuda Indonesia diambang kebangkrutan karena buruknya penerapan GCG di masa lalu dan performa keuangan yang memburuk akibat adanya pandemi Covid-19 yang mengharuskan PT Garuda Indonesia (Persero) memangkas rute penerbangannya menjadi lebih sedikit. Menanggapi hal tersebut, diperlukan adanya keterlibatan dari pemangku kepentingan untuk mengatasi potensi kebangkrutan. Mengingat pentingnya penerapa GCG yang baik dan nilai moral kementrian BUMN manajemen Garuda sampai saat ini masih berfokus untuk pemulihan performa keuangan menggunakan upaya restrukturisasi performa keuangan, salah satunya adalah restrukturisasi utang.

\section{METODE}

Melalui kajian literatur, penelitian ini dimaksudkan untuk mengkaji dampak good corporate governance pada performa finansial secara lebih mendalam. Dengan menganalisis model hubungan good corporate governance dengan performa keuangan. Penelitian ini memakai teknik pengumpulan data dari data pihak kedua. Pengumpulan data pihak kedua dilakukan dengan studi literatur dengan cara mendalami dan melakukan observasi pada dokumen yang berhubungan dengan GCG terutama tentang pengaruh GCG terhadap performa keuangan pada perusahaan. Dengan menggunakan beberapa penelitian terdahulu, analisis literatur review dilakukan untuk menganalisis hasil berupa meta analisis yang disajikan dalam bentuk fenomena penelitian agar pengungkapan menjadi lebih jelas.

Untuk menentukan studi literatur terdapat lima langkah yang dikemukakan oleh (Creswell, 2015). Langkah pertama adalah mencari literatur dengan menggunakan istilah kata kunci yang mengidentifikasikan topik penelitian, kata kunci yang dipakai dalam penelitian ini adalah GCG; Studi Literatur; Performa Keuangan. Langkah kedua yaitu, mengklasifikasikan kategori literatur sebagai tahap awal pencarian dengan menentukan jurnal yang ingin dituju yaitu jurnal akuntansi, jurnal manajemen, jurnal 
Felicia Siswanto', I Wayan Alvin Kertanegara', Kevin'3, Rahayu Ningsih4, Carmel Meiden $^{5}$ : Kajian Literatur: Pengaruh Tata Kelola PerusahaanPadaPerforma Keuangan

ekonomi, dan jurnal bisnis. Lalu menentukan tempat penelitian dalam artikel ini memilih negara Indonesia, dan mengkategorikan tahun dari 2014 sampai dengan 2021. Langkah ketiga yaitu menentukan kriteria inklusi atau eksklusi yang berguna untuk memilih antara artikel atau dokumen yang akan digunakan dan tidak digunakan.

Kriteria inklusi yang dipakaipada penelitian iniadalah sebagai berikut: 1 . Bertemakan Good Corporate Governance dan Performa Keuangan; 2. Di publish dari Jurnal Akuntansi, Bisnis, Ekonomi dan Manajemen; 3. Tahun penelitian 2014 s/d 2021. Kemudian kriteria eksklusinya yaitu: 1. Selain bertemakan Good Corporate Governance dan Performa Keuangan; 2. Selain di publish dari Jurnal Akuntansi, Bisnis, Ekonomi dan Manajemen; 3. Tahun penelitian di bawah 2014. Berdasarkan kriteria inklusi di atas kami menemukan 20 artikel dari 21.229 artikel yang bersumber dari database Google Scholar dan Sinta. Langkah keempat membuat catatan yang menggambarkan peta literatur. Langkah kelima menulis tinjauan pustaka dengan gaya penulisan berdasarkan gambaran rinci, analisis studi, pendekatan studi, dan tema atau pokok bahasan. Di bawah ini merupakan gambaran peta literatur dari kelima tahapan di atas:

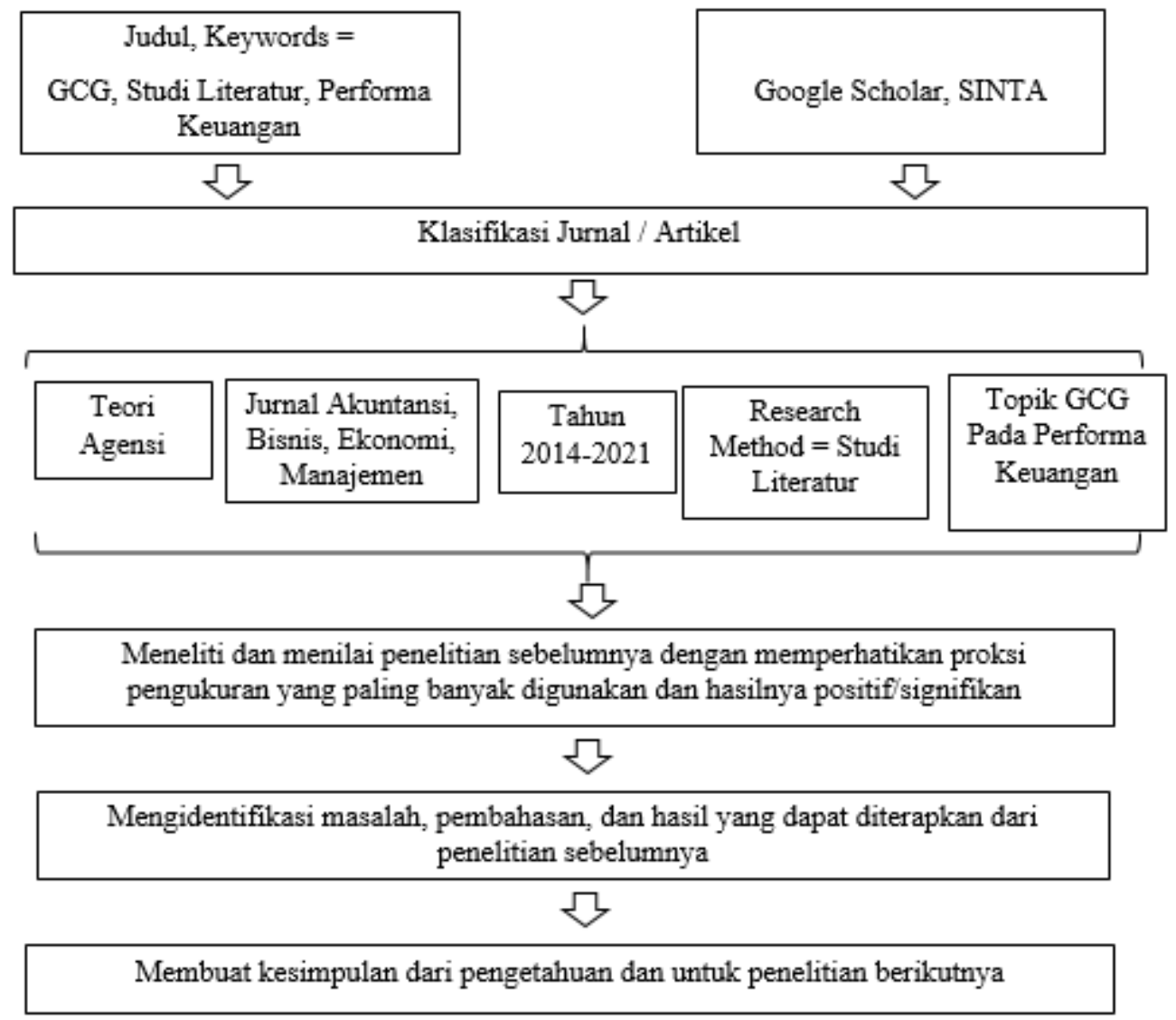

Gambar 1. Model Penelitian

Sumber: Hasil Olahan (2021) 
Felicia Siswanto', I Wayan Alvin Kertanegara², Kevin³, Rahayu Ningsih", Carmel Meiden $^{5}$ : Kajian Literatur: Pengaruh Tata Kelola PerusahaanPadaPerforma Keuangan

\section{HASIL DAN PEMBAHASAN}

Berdasarkan sumber pencarian mengenai GCG dan performa keuangan pada mesin pencari Google Scholar terdapat 21.000 artikel dan 229 artikel pada mesin pencari Sinta. Sebagian besar penelitian menggunakan variabel yang berbeda-beda yang dapat mempengaruhi performa keuangan perusahaan. Dari penelitian terdahulu yang menganalisis dampak good corporate governance pada performakeuangan, maka dapat diartikan sebagai berikut: dalam konteks good corporate governance dan performa keuangan perlu memperhatikan adanya teori agensi, karena dalam penerapannya teori agensi sangat memiliki pengaruh terhadap performakeuangan tersebut. Membatasi adanya konflik agensi antara pemilik dengan manajemen dapat memberikan arti bahwa performakeuangan perusahaan tersebut berjalan dengan baik sesuai dengan penerapan tata kelola perusahaan. Dari 20 artikel penelitian sebelumnya teori agensi merupakan teori yang banyak diterapkan dalam penelitian pengaruh good corporate governance pada performa keuangan.

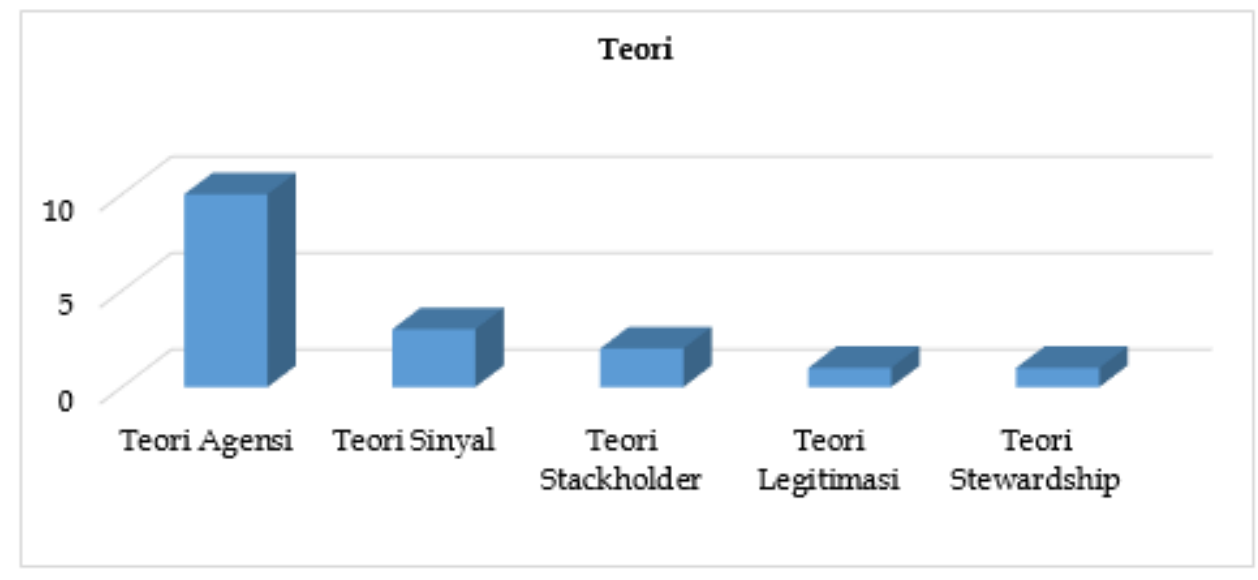

Gambar 2. Teori yang Digunakan

Sumber: Hasil Olahan (2021)

Performa keuangan perusahaan merupakan cerminan mengenai situasi keuangan suatu perusahaan yang menggambarkan baik atau buruknya situasi keuangan perusahaan dengan menggunakan analisis alat-alat keuangan untuk menganalisa. Agar perusahaan berjalan dengan ampuh dan berdaya guna serta dapat mencapai tujuan perusahaan, penilaian performa keuangan merupakan satu dari banyak cara paling tepat yang dapat manajemen lakukanuntuk memenuhi hak-hak para pemegang saham. Performa keuangan merupakan faktor yang menunjukkan suatu organisasi bekerja dengan efisien dan efektif dalammencapai tujuan yang ingin direalisasikan. Efektif apabila manajemen memiliki kapasitas untuk mencapi tujuan dengan tepat dan efisiensi apabila antara input dengan output memperoleh keluaran 
Felicia Siswanto', I Wayan Alvin Kertanegara², Kevin³, Rahayu Ningsih", Carmel

Meiden $^{5}$ : Kajian Literatur: Pengaruh Tata Kelola PerusahaanPadaPerforma Keuangan

yang optimal (Harsalim, 2017). Dengan adanya performakeuangan, investor dapat melihat bagaimana cara suatu perusahaan dapatmengoptimalkan pemakaian asetnya untuk menghasilkan keuntungan, hal ini sejalan dengan tujuan GCG yaitu penggunaan aset yang efektif dan optimal.

Banyak penelitian yang menjelaskan pengukuran good corporate governancepada performa finansial. Penilaian performa finansial menjadi hal utama dan paling penting bagi investor-investor sebagai dasar pengambilan keputusan, bagi perusahaan penilaian performa keuangan dapat digunakan untuk meninjau pencapaian perusahaan dalam suatu periode dan dapat digunakan sebagai acuan untuk penentuan strategi perusahaan kedepannya. Pada tabel 1 ditunjukkan variabel-variabel dari penelitian terdahulu.

Hasil analisis dari 20 artikel penelitian sebelumnya terdapat empat proksi pengukuran good corporate governance yang banyak digunakan pada performa keuangan, yaitu komisaris independen, kepemilikan manajerial, kepemilikan institusional, dan komite audit. Untuk proksi pengukuran performa keuangan menggunakan ROA.

Wardani dan Suwarno (2014) meneliti pengaruh GCG pada performa keuangan perusahaan sektor manufacturing yang terdaftar di BEI dalam rentang tahun 2017-2019 dengan menggunakan proksi pengukuran kepemilikan publik, dewan komisaris independen, dankepemilikan manajerial. Penelitian tersebut menunjukkan kepemilikan publik dan dewan komisaris independen tidak memberikan dampak pada performa keuangan perusahaan sedangkan kepemilikan manajerial memberikan dampak positif pada performa keuangan perusahaan.

Erbert Effendy (2015) meneliti pengaruh GCG terhadap kinerja keuangan pada perusahaan anggotaCGPI yang terdaftar di BEI terhitung dari 2008-2012 dengan proksi pengukuran dewan komisaris, proporsi komisaris independen, kehadiran dewan komisaris dari Institusional Investor, dan ukuran perusahaan, leverage,yangcontrolling variable-nyaadalahfirm age dan firm size. Hasil penelitian menandakan Board of Commissioners, Independent Commissioners, dan Board of Commissioners Attendance dari Institutionalinvestor tidak berpengaruh terhadap performa keuangan. Sedangkan controlling variablefirm size leverage berpengaruh terhadap performa keuangan perusahaan.

Mulyadi (2016) meneliti pengaruh GCG terhadap kinerja keuangan pada seluruh perusahaan dalam daftar Bursa Efek Indonesiaterhitung dari2010-2011. Komisaris Independen memiliki pengaruh negatif terhadap performa keuangan dalam penelitian ini, yang menandakan bahwa pengawasan yang dilaksanakan oleh dewankomisaris telahmeminimalisir praktik manajemen laba. Komite audit tidak berpengaruh dengan performa keuangan perusahaan.

Sudrajat dan Sukmajati (2016) meneliti pengaruh GCG pada performa keuangan perbankan umum syariah pada tahun 2012-2016 yang menggunakan proksi pengukuran 
Felicia Siswanto', I Wayan Alvin Kertanegara', Kevin'3, Rahayu Ningsih4, Carmel Meiden $^{5}$ : Kajian Literatur: Pengaruh Tata Kelola PerusahaanPadaPerforma Keuangan

ukuran ukuran dewan direksi, komite audit, ukuran dewan komisaris, dan ukuran dewan pengawas syariah dengan rasio ROA. Dari penelitian ini, ukuran komite audit, ukuran dewan pengawas syariah, ukuran dewan komisaris dan ukuran dewan direksi, secara simultan tidak menunjukan pengaruh berarti terhadap ROA.

Tabel 1. Variabel Penelitian Terdahulu

\begin{tabular}{|c|c|c|}
\hline No & Variabel & Total \\
\hline 1 & $\mathrm{ROA}$ & 16 \\
\hline 2 & ROE & 9 \\
\hline 3 & Kepemilikan Institusional & 8 \\
\hline 4 & CGPI & 1 \\
\hline 5 & DER & 1 \\
\hline 6 & Dewan Komisaris & 7 \\
\hline 7 & ROI & 1 \\
\hline 8 & Komite Audit & 11 \\
\hline 9 & NPM & 1 \\
\hline 10 & Tobin's Q & 1 \\
\hline 11 & PBV & 1 \\
\hline 12 & EPS & 1 \\
\hline 13 & Kepemilikan Manajerial & 8 \\
\hline 14 & Akuntabilitas & 1 \\
\hline 15 & $\mathrm{CA}$ & 1 \\
\hline \multirow[t]{2}{*}{16} & Dewan Direksi & 6 \\
\hline & Dewan Komisaris & \\
\hline 17 & Independen & 4 \\
\hline 18 & Transparansi & 1 \\
\hline 19 & Capital Adequacy Ratio Car & 1 \\
\hline 20 & Komite Audit Independen & 2 \\
\hline 21 & Kepemilikan Publik & 1 \\
\hline 22 & Kepemilikan Asing & 1 \\
\hline 23 & Kualitas Audit & 1 \\
\hline 24 & Dewan Pengawas Syariah & 2 \\
\hline 25 & Komisaris Independen & 8 \\
\hline 26 & Responsibilitas & 1 \\
\hline 27 & Independensi & 1 \\
\hline 28 & Kewajaran & 1 \\
\hline \multirow[t]{2}{*}{29} & Modal Intelektual & 1 \\
\hline & Kehadiran Dewan & \\
\hline 30 & Komisaris & 1 \\
\hline 31 & Komposisi Aset & 1 \\
\hline 32 & Ukuran Perusahaan & 1 \\
\hline 33 & Pertumbuhan Penjualan & 1 \\
\hline
\end{tabular}

Sumber: Hasil Olahan (2021) 
Felicia Siswanto', I Wayan Alvin Kertanegara², Kevin³, Rahayu Ningsih", Carmel

Meiden $^{5}$ : Kajian Literatur: Pengaruh Tata Kelola PerusahaanPadaPerforma Keuangan

I. B Made Puniayasa dan Nyoman Triaryati (2016) meneliti dampak GCG, intelektual, dan struktur kepemilikan terhadap performa keuangan perusahaan pada perusahaan yang masuk ke dalam indeks Corporate Governance Perception Index(CGPI) pada tahun 2012-2014 dengan proksi pengukuran GCG, modal intelektual, kepemilikan manajerial, dan kepemilikan institusional.Hasil dari penelitiantersebut menunjukkan bahwa kepemilikian institusional dan GCG tidak memiliki pengaruhpadaperforma keuangan perusahaan. Sedangkan modal intelektual dan kepemilikan manajerial memiliki pengaruh positif padaperforma keuangan.

Novi et al(2017) meneliti pengaruh GCG padaperforma keuangan pada perusahaanyang terdaftar di BEI pada sektor perbankan dengan rentang tahun 20122015 dengan menggunakan proksi pengukuran: komite audit, dewan direksi, dewan komisaris independen, dan rapat dewan komisaris.Hasil dari penelitian menunjukkan rapat dewan komisaris tidak memiliki pengaruhpadaperforma keuangan, dewan direksi memiliki pengaruhpadaperforma keuangan, dan dewan komisaris independen tidak memiliki pengaruhpadaperforma keuangan.

Harsalim (2017) meneliti pengaruh GCG padaperforma keuanganperusahaan peserta Corporate Governance Perception Index (CGPI) pada tahun 2008-2013 dengan menggunakan proksi pengukuran: GCG sebagai variabel independen, komposisi aset, ukuran perusahaan, pertumbuhan penjualan sebagai variabel kontrol, dan ROA, ROE, serta Tobin's Q (performa pasar) sebagai variabel dependen. Hasil dari penelitian menunjukkan bahwa GCG tidak memiliki pengaruh terhadap performa keuangan yang diukur dengan ROA. GCG tidak memiliki pengaruh terhadap performakeuangan yang diukur dengan ROE. GCG tidak memiliki pengaruh terhadap performa keuangan yang diukur dengan Tobin's $Q$.

Sejati et al., (2018) meneliti pengaruh GCG padaperforma keuangan perusahaan pada sektorproperty\&real estate yang ada di BEI dalam rentang tahun 2014-2016 dengan menggunakan proksi pengukuran: komite audit, dewan direksi, kepemilikan manajerial, dewan komisaris independen, dan kepemilikan institusional.Hasil dari penelitian menunjukkan dewan direksi, dan dewan komisarismemiliki pengaruh negatif terhadap performa keuangan. Sedangkan kepemilikan institusional, komite audit, dan kepemilikan manajerial tidak memiliki pengaruh terhadap performa keuangan.

Hamka, Patra, dan Jasman (2019) melakukan penelitian GCG pada performa keuangan PT Unilever Indonesia untuk Periode 2010-2017 dengan menggunakan, (Managerial Ownership) MO, (Institutional Ownership) IO, serta (Independent Comissioners) IC untuk menjadi variabel bebas yang merupakan proxy GCG, dan performa keuangan sebagai variabel terikat, serta (cash flow return on aset). Penelitian menghasilkan perhitungan dimana (Managerial Ownership) MO dan (Institutional Ownership) IO 
Felicia Siswanto', I Wayan Alvin Kertanegara², Kevin³, Rahayu Ningsih", Carmel

Meiden $^{5}$ : Kajian Literatur: Pengaruh Tata Kelola PerusahaanPadaPerforma Keuangan

menunjukan nilai signifikasi yang positif, namun variabel (Independent Comissioner) IC menunjukan tidak adanya pengaruh sama sekali bagi Performa Keuangan.

Sari, Riasning, Rini (2019) meneliti pengaruh GCG pada perusahaan-perusahaan yang terdaftar di Bursa Efek Indonesia pada sektor manufakturdalam rentang tahun 2015-2017, untuk menilai penerapan-nya pada performa keuangan-nya, maka digunakan proksi-proksi. Performa Keuangan-nya dilihat berdasarkan rasio ROA. Proksi variable GCG terbagi atas (Corporate Social Responsibility) CSR, (Audit Committee) CA, (Board of Commissioners) BOC, (Board of Independent Commissioners) BOIC, (Institutional Ownership) IO, (Managerial Ownership) MO. Berdasarkan Hasil dari penelitian, terlihat bahwa (Corporate Social Responsibility)CSR, (Audit Committee) CA, (Board of Commissioners) BOC, (Board of Independent Commissioners) BOIC, (Institutional Ownership) IO, dan (Managerial Ownership) MO, menunjukan nilai positif bagi performa keuangan.

Diyanty dan Yusniar (2019) meneliti pengaruh mekanisme GCG terhadap performa keuangan perusahaan yang terdaftar di BEI pada sektor perbankan. Dengan menggunakan proksi pengukuran CAR, komite audit, proporsi komisaris independent, dewan komisaris, serta dewan direksi untuk variabel GCG dan (Return On Aset) ROAuntuk performa keuangan. Dari penelitian ini, baik CAR, komite audit, proporsi komisaris independen, serta dewan komisaris tidak memperlihatkan pengaruh yang signifikan terhadap ROA, hanya dewan direksi saja yang memperlihatkan pengaruh positif dan signifikan pada ROA.

Situmorang dan Simanjuntak (2019) meneliti dampak GCG pada performa keuangan perusahaan-perusahaan yang terdaftar di BEI pada sektor perbankan. Dengan menggunakan proksi pengukuran komposisi dewan direksi, komposisi komisaris independen, dan persentase kepemilikan institusional terhadap Tingkat Pengembalian Ekuitas. Kesimpulan dari penelitian tersebut menunjukkan komposisi komisaris independen, persentase kepemilikan institusional, dan komposisi dewan direksi tidak memberikan dampak yang berarti dengan arah koefisien negatif terhadap Tingkat Pengembalian Ekuitas. Sedangkan secara simultan persentase komposisi komisaris independen, persentase kepemilikan institusional, dan komposisi dewan direksi memiliki pengaruh signifikan terhadap Timbal Balik Ekuitas dengan arah koefisien positif.

Islamiah dan Pratiwi (2020) meneliti penerapan GCG pada PT. Matahari DepartmentStore Tbk, untuk dinilai seberapa besar manfaat-nya pada performa keuangan, dengan menggunakan proksi pengukuran GCG, seperti Board of Directors (X1), Commissioners Board Size (X2), serta Audit Committee (X3) menjadi variabel bebas, untuk variabel terikatnya, menggunakan rasio $R O A(Y)$ untuk mengukur performa keuangan-nya. Berdasarkan Hasil dari penelitian yang dilakukan terlihat bahwa (X1) dan (X2) tidak menunjukan nilai signifikan terhadap ROA, untuk proxy Audit Committee 
Felicia Siswanto', I Wayan Alvin Kertanegara', Kevin'3, Rahayu Ningsih4, Carmel Meiden $^{5}$ : Kajian Literatur: Pengaruh Tata Kelola PerusahaanPadaPerforma Keuangan

tidak menunjukan nilai yang signifikan pada (Y). Ini berarti bahwa, jumlah anggota dewan yang semakin meningkat, makatugas yang akan dibagi ke masing-masing anggota-nya akan menjadi lebih jelas, dimana akan berdampak positif bagi stakeholder. Begitu juga, komite audit memiliki tugas yaitu memberikan pengawasan secara menyeluruh.

Marietza, Wijayanti, dan Agusrina (2020) meneliti pengaruh GCG dan Reporting Lag terhadap performa keuangan perusahaan menggunakan proksi Board of Independence Commissioners (X1), Managerial Ownerships (X2), Institutional Ownership (X3), Foreign Ownership (X4), Independent Audit Committee (X5), dan Audit Quality (X6). ProxyPerforma Keuangan-nya, yaitu ROA (Y1), ROE (Y2), dan EPS (Y3). Berdasarkan Hasil dari penelitian terlihat bahwa proporsi $(X 1),(X 3)$, dan (X4) menunjukan pengaruh pada (Y1) dan (Y2). (X2) menunjukan pengaruh pada (Y2). (X5) dan (X6) menunjukan pengaruh negatif pada (Y1), (Y2), dan (Y3).

Novitasari, Endiana, dan Arizona (2020) meneliti pengaruh GCG terhadap performa keuangan perusahaan-perusahaan yang ada di sektor perbankan dan masuk dalam Bursa Efek Indonesia.Dengan proksi pengukuran komite audit, ukuran dewan direksi, ukuran dewan komisaris, kepemilikan manajerial, dan kepemilikan institusional sebagai faktoryang mempengaruhi, dan performa keuangan sebagai faktor yang dipengaruhi. Hasil penelilitan memperlihatkan adanya pengaruh positif dari struktur kepemilikan manajerial dan struktur kepemilikan institusionalpada performa keuangan perusahaan, sementara baik ukuran dewan direksi, komite audit, dan ukuran dewan komisaris tidak menunjukan adanya pengaruh padaperforma keuangan.

Yunina dan Nisa (2020) meneliti dampak GCG terhadap performa keuangan bank umum syariah tahun 2015-2017 dengan menggunakan proksi pengukuran komite audit independen dan dewan komisaris independenpadaperforma keuangan yang diukur dengan rasio Timbal Balik Ekuitas. Kesimpulan dari penelitian tersebut menunjukkan komite audit independen dan dewan komisaris independen secara simultan memberikan dampak terhadap performa keuangan, namun secara terpisah komite audit independen memberikan dampak positif, sedangkan dewan komisaris independen memberikan dampak negatif.

Setiawan dan Setiadi (2020) meneliti pengaruh GCG terhadap performa keuangan perusahaan-perusahaan yang terdaftar di BEI pada sektor industri barang konsumsi. Dengan menggunakan proksi pengukuran yaitu komite audit, komisaris independen, kepemilikan manajerial, dan kepemilikan institusional pada Pengembalian Atas Aset (ROA). Hasil dari penelitian tersebut menunjukkan komisaris independen memberikan dampak positif dan signifikan padaperforma keuangan (ROA), komite audit independen tidak memberikan dampakpadaperforma keuangan (ROA), kepemilikan institusional memberikan dampak positif dan signifikan padaperforma 
Felicia Siswanto', I Wayan Alvin Kertanegara², Kevin³, Rahayu Ningsih", Carmel

Meiden $^{5}$ : Kajian Literatur: Pengaruh Tata Kelola PerusahaanPadaPerforma Keuangan

keuangan (ROA), dan kepemilikan manajerial memberikan dampakpadaperforma keuangan (ROA).

Islamiah dan Pratiwi (2020) meneliti pengaruh GCG terhadap performa keuangan pada PT Matahari Department Store Tbk dalam periode 2009-2018 dengan menggunakan proksi pengukuran dewan direksi, ukuran dewan komisaris, dan komite audit. Hasil dari penelitian menunjukkan dewan direksi dan ukuran dewan komisaris tidak memiliki pengaruh terhadap ROA. Sedangkan komite audit memiliki pengaruh terhadap ROA.

Laksono dan Kusumaningtias (2021) meneliti pengaruh GCG terhadap performa keuangan dan nilai perusahaan pada sektor aneka industri pada tahun 2016-2018 dengan menggunakan proksi pengukuran komite audit, dan komisaris independen. Hasil dari penelitian tersebut menunjukkan bahwa komite audit, dan komisaris independen tidak memberikan dampak terhadap performa keuangan.

Sulaiman et al (2021) meneliti pengaruh GCG pada performa perusahaan terdaftar di BEI (Bursa Efek Indonesia) pada sektor industri barang konsumsi. Dengan menggunakan proksi pengukuran GCG pada kepemilikan manajerial, komisaris independen, komite audit, dan kepemilikan institusional terhadap performa perusahaan dengan rasio ROE. Dari penelitian ini, proksi komite audit dan komisaris independen menunjukkan adanya dampak negatif, dan signifikan terhadap performa perusahaan, kepemilikan manajerial pun tidak memperlihatkan pengaruh yang relevan terhadap performa perusahaan. Terkecuali untuk kepemilikan institusional menunjukan pengaruh positif serta relevan pada performa perusahaan.

Berdasarkan penelitian di atas untuk memaksimalkan keuntungan perusahaan, perusahaan harus menerapkan struktur kepemilikan yang ketat agar pihak-pihak yang berkepentingan dapat meningkatkan pengawasan manajemen yang lebih optimal dan efektif sehingga manajemen lebih berhati-hati dalam menerapkan performa keuangan. Selain itu, peran komisaris independen yang besar menandakan bahwa mereka bisa menjalankan tugas dan wewenang mereka untuk mengawasi dan mengontrol tindakantindakan pada direktur eksekutif hal ini sejalan dengan prinsip dari teori keagenan. Komite audit berperan dalam perusahaan yaitu membantu dewan komisaris untuk melaksanakan tugasnya dan memberikan pengawasan secara keseluruhan.

\section{KESIMPULAN}

Penelitian terdahulu yang digunakan dalam penelitian ini adalah penelitian kuantitatif dengan jumlah artikel berjumlah20 artikel. Terdapat 6 faktor yang memiliki pengaruh terhadap performa keuangan, diantaranya: Kepemilikan institusional terdapat 6 hasil, kepemilikan manajerial terdapat 5 hasil, komite audit terdapat 4 hasil, dewan komisaris terdapat 2 hasil, dewan komisaris independen terdapat 3 hasil, dan dewan direksi terdapat 4 hasil. Sedangkan, yang tidak memiliki pengaruh, diantaranya: 
Felicia Siswanto', I Wayan Alvin Kertanegara², Kevin³, Rahayu Ningsih", Carmel Meiden $^{5}$ : Kajian Literatur: Pengaruh Tata Kelola PerusahaanPadaPerforma Keuangan

Kepemilikan institusional terdapat 2 hasil, kepemilikan manajerial terdapat 2 hasil, komite audit terdapat 9 hasil, dewan komisaris terdapat 6 hasil, dewan komisaris independen terdapat 1 hasil, dan dewan direksi terdapat 4 hasil.

Penerapan konsep GCG perlu diterapkan di dalam perusahaan agar pengelolaan perusahaan dapat berjalan dengan baik, efektif, dan efisien. Selain itu, penerapan tata kelola perusahaan yang baik dapat membuat perusahaan mendapatkan investor yang menanamkan modalnya karena investor percaya dan yakin bahwa modal yang ditanamkannya dapat dipergunakan dengan baik sehingga perusahaan dapat berlangsung serta dapat mencapai tujuannya. Selain itu, pemberlakuan teori agensi perlu diterapkan dalam perusahaan agar terhindari dari konflik keagenan.

\section{DAFTAR PUSTAKA}

Creswell, J. W. (2015). What Is a Literature Review? In Pearson. https://doi.org/10.4135/9781473957756.n2

Diyanty, M., \& Yusniar, M. W. (2019). Pengaruh Mekanisme Good Corporate Governance Terhadap Kinerja Keuangan Padaperbankan Yang Terdaftar Di Bursa Efek Indonesia (Bei). JWM (Jurnal Wawasan Manajemen), 7(1), 49. https://doi.org/10.20527/jwm.v7i1.175

Erbert Effendy. (2015). Pengaruh Good Corporate Governance terhadap Kinerja Keuangan. $4(2), 1-12$.

Hamka, F., Patra, I. K., \& Jasman, J. (2019). PENGARUH PENERAPAN GOOD CORPORATE GOVERNANCE TERHADAP KINERJA KEUANGAN (Studi Kasus pada PT. Unilever Indonesia Periode 2010-2017). Jurnal Manajemen STIE Muhammadiyah Palopo, 4(1), 14-19. https:/ / doi.org/10.35906/jm001.v4i1.298

Harsalim, J. P. (2017). Pengaruh Good Corporate Governance terhadap Kinerja Keuangan pada Peserta CGPI yang terdaftar di BEI Periode 2008-2013. Jurnal Ilmiah Mahasiswa Universitas Surabaya, 6(2), 17-34.

I. B Made Puniayasa dan Nyoman Triaryati. (2016). Pengaruh Good Corporate Governance, Struktur Kepemilikan Dan Modal Intelektual Terhadap Kinerja Keuangan Perusahaan Yang Masuk Dalam Indeks Cgpi. E-Jurnal Manajemen Universitas Udayana, 5(8), 5305-5332.

Irawati, Delta dan Sutarjo, A. (2020). Pengaruh Good Corporate Governance terhadap Kinerja Keuangan Perusahaan Sektor Badan Usaha Milik Negara (BUMN) yang

Terdaftar di Bursa Efek Indonesia (BEI) Periode 2012-2016. Almana: Jurnal Manajemen Dan Bisnis, 2(2), 277-288. https:/ / doi.org/10.36555/almana.v5i1.1579

Islamiah, Muslimah dan Pratiwi, A. (2020). PENGARUH GOOD CORPORATE GOVERNANCE TERHADAP KINERJA KEUANGAN PADA PT. MATAHARI DEPARTMENT STORE Tbk. Jurnal Ekonomi Balance, 16(1), 59-67. https://doi.org/10.26618/jeb.v16i1.3467 
Felicia Siswanto', I Wayan Alvin Kertanegara², Kevin³, Rahayu Ningsih", Carmel

Meiden $^{5}$ : Kajian Literatur: Pengaruh Tata Kelola PerusahaanPadaPerforma Keuangan

Jensen, M. C., \& Meckling, W. H. (1976). Theory of the firm: Managerial behavior, agency costs and ownership structure. Corporate Governance: Values, Ethics and Leadership, 77-132. https:// doi.org/10.2139/ssrn.94043

Laksono, B. S., \& Kusumaningtias, R. (2021). Pengaruh Good Corporate Governance Terhadap Kinerja Keuangan dan Nilai Perusahaan Sektor Aneka Industri Tahun 2016-2018. Jurnal Akuntansi Unesa, 9(2), 1-12.

Marietza, F., Wijayanti, I. O., \& Agusrina, M. (2020). Pengaruh Good Corporate Governance Dan Reporting Lag Terhadap Kinerja Keuangan Perusahaan (Studi Empiris Pada Perusahaan Yang Terdaftar Di Bursa Efek .... Jurnal Riset Terapan ..., $4,116$.

Mulyadi, R. (2016). Pengaruh Corporate Governance Terhadap Kinerja Keuangan. Jurnal Akuntansi, 3(1), 59-74. https:/ / doi.org/10.4324/9781315832661

Nasution, M., \& Setiawan, D. (2007). Pengaruh Corporate Governance Terhadap Manajemen Laba Di Industri Perbankan Indonesia. Simposium Nasional Akuntansi $X$, Juli,1-26.

http://www.starwoodhotels.com/corporate/about/investor/governance.html

Novi Yanti, Elly Rasyid, dan F. (2017). Pengaruh Good Corporate Governance Terhadap Kinerja Keuangan. Fundamental Management Journal, 2(1), 5-13.

Novitasari, Inka; Endiana, I Dewa Made; Arizona, P. E. (2020). Pengaruh Mekanisme Good Corporate Governance terhadap Kinerja Keuangan Perusahaan Perbankan yang Terdaftar di BEI. Jurnal Kharisma, 5(1). https://doi.org/10.34204/jiafe.v5i2.2057

Sari, P. M. Y. I., Riasning, N. P., \& Rini, G. A. I. S. (2019). Pengaruh Good Corporate Governance Terhadap Kinerja Keuangan Perusahaan Pada Perusahaan Manufaktur yang Terdaftar di BEI Tahun 2015-2017. Jurnal Riset Akuntansi, 9(2), 4855.

Sejati, E. P., Titisari, K. H., \& Chomsatu, Y. (2018). Pengaruh Good Corporate Governance Terhadap Kinerja Keuangan Pada Perusahaan Manufaktur Industri Real Estate Dan Property Di Bei Periode 2014-2016. Seminar Nasional Dan Call for Paper, 500-512.

Setiawan, O., \& Setiadi, I. (2020). Pengaruh Good Corporate Governance Terhadap Kinerja Keuangan Pada Sektor Barang Konsumsi di BEI. Kompartemen: Jurnal Ilmiah Akuntansi, 18(1), 13-21. https:// doi.org/10.30595/kompartemen.v18i1.6606

Situmorang, C. V., \& Simanjuntak, A. (2019). Pengaruh Good Corporate Governance Terhadap Kinerja Keuangan Perusahaan Perbankan Yang Terdaftar Di Bursa Efek Indonesia. JURNAL AKUNTANSI DAN BISNIS: Jurnal Program Studi Akuntansi, 5(2), 160. https://doi.org/10.31289/jab.v5i2.2694

Sudrajat, M., \& Sukmajati, A. (2018). Pengaruh Good Corporate Governance Terhadap Kinerja Keuangan Bank Umum Syariah Periode 2012-2016. Jurnal STIE Swasta 
Felicia Siswanto', I Wayan Alvin Kertanegara'2, Kevin ${ }^{3}$, Rahayu Ningsih", Carmel

Meiden $^{5}$ : Kajian Literatur: Pengaruh Tata Kelola PerusahaanPadaPerforma Keuangan

Mandiri, 1-14.

Sulaiman, S. N., Morasa, J., Gamaliel, H., \& Morasa, J. (2021). Pengaruh Good Corporate Governance Terhadap Kinerja Perusahaan Consumer Goods Industry Yang Terdaftar Di Bei. Jurnal EMBA: Jurnal Riset Ekonomi, Manajemen, Bisnis Dan Akuntansi, 9(1), 470-484. https:// doi.org/10.35794/emba.v9i1.32241

Wahyuni, A. R., Basalamah, S., \& Mursalim, M. (2020). Analisis Implementasi Good Corporate Governance (GCG) Pada Bank Sulselbar Syariah. Jurnal Ekonomika, 4, 6069. http://journal.lldikti9.id/Ekonomika/article/view/504

Wardani, E. K., \& Suwarno, A. E. (2014). Pengaruh Good Corporate Governance Terhadap. Diponegoro Journal Of Accounting, 4(3), 67-77.

Yunina, F., \& Nisa, N. (2020). Pengaruh Good Corporate Governance Terhadap Kinerja Keuangan Bank Umum Syariah Tahun 2015-2017. Jurnal Akuntansi Muhammadiyah, 10(1). https:/ / doi.org/10.37598/jam.v10i1.779. 